ХIMIЯ.

ФАРМАЦЕВТИЧНІ ТЕХНОЛОГІї.

БІОМЕДИЧНА ІНЖЕНЕРІЯ

UDC 665.753

V. Lyalin, PhD, Assoc. Prof.,

Y. Drevnitskaya, $\mathrm{PhD}$

Odessa National Polytechnic University, 1 Shevchenko Ave., Odessa, Ukraine, 65044; e-mail: vlyalin40@gmail.com

\title{
PURIFICATION OF FUEL FRACTIONS OF PETROLEUM PRODUCTS FROM SULFUR COMPOUNDS
}

В.В. Лялін, О.Л. Древницька. Очистка паливних фракцій нафтопродуктів від сірковмісних органічних сполук. Значний збиток навколишньому середовищу наносить спалювання моторних палив. Необхідність захисту довкілля привела до різкого посилення вимог до екологічних властивостей автомобільних палив, особливо до вмісту в них сірки. В сучасних умовах відбувається постійне зниження якості нафтової сировини, що надходить на переробку. 3 іншого боку підвищуються екологічні вимоги до якості палив. Все це робить актуальним вирішення проблеми знесірчення товарних нафтопродуктів. Підвищення якості нафтопродуктів можливо за рахунок видалення 3 них сірки. Тому знесірчення або десульфуризація - це одна 3 головних задач виробництва якісних нафтопродуктів. Метою цієї роботи є розробка і дослідження сучасних методів знесірчення нафти і їх порівняльна характеристика. Розглянуті сучасні технології по очищенню моторних палив від сполук сірки: каталітичного гідроочищення та окислювальні технології. Наведені експериментальні дані по окислювальному знесірченню нафтопродуктів перекисом водню $з$ каталітичною системою та сумісний метод окисленням киснем в присутності вторинних спиртів 3 метою одержання палив, що мають вміст сірки менше 10 ppm, що відповідає стандарту ЄВРО-6. В результаті проведених досліджень показано, що ефективність процесу окислювального знесірчення паливних фракцій залежить від вмісту в них ненасичених сполук. Ступень знесірчення сильно знижується при високому вмісті останніх. При окисленні перекисом водню гідроочищених паливних фракцій з низьким вмістом ненасичених вуглеводнів вдається знесірчувати їх до вмісту сірки 10 ррm і менш. Проте, висока вартість окисника заважає впровадженню цього способу у виробництво. Тому у роботі уперше досліджено неописаний в літературі, поєднаний процес окислення сірчистих сполук в паливах киснем у присутності вторинних спиртів. Показано, що процес окислення 3 використанням вторинних спиртів протікає з великою швидкістю і підвищує ступень знесірчення. При цьому процес не вимагає дорогого реагенту - пероксиду водню, що забезпечує високи економічні показники і дає можливість використовувати його як альтернативу методу каталітичної гідрогенізації.

Ключові слова: гідроочищення, моторні палива, екстракція, окислення, вторинні спирти, перекис водню

V. Lyalin, Y. Drevnitskaya. Purification of fuelfractions of petroleum products fromsulflr compounds. Significant damage to the environment causes burning of motor fuels. One of the most urgent problems for oil refineries around the world is the reduction of sulfur content, which directly affects the emission of sulfur oxides. The need for environmental protection has led to a sharp increase in requirements for the environmental properties of automotive fuels, especially the content of sulfur in them. Sulfur combustion products poison the catalysts of the burning of products of incomplete combustion of hydrocarbons - carbon monoxide and nitrogen oxides, while emissions to the atmosphere of sulfur oxides when sulfur fuels are burned out cause acid rain falls. In addition, compounds of sulfur, present in the fractions of the direct race of oil, worsen a number of operational properties of motor fuels, so modern fuel technologies provide for the mandatory purification of these fractions from sulfur. In Europe, the emission limit value for exhaust gases, which is EURO-5 - $10 \mathrm{mg} / \mathrm{kg}$. For the removal of sulfur from hydrocarbon fractions of primary oil refining, the most common method is the catalytic hydrotreatment, based on catalytic hydrogenation of hydrogen sulfide compounds at high pressure and temperature. At the same time, organic compounds of sulfur are destroyed to hydrocarbons and hydrogen sulfide, the latter is separated from petroleum products. Destruction of organosilicon compounds can be avoided if oxidation methods are used for dehydration, and oxidized sulfur compounds can be used in various sectors of the national economy. The theme of this work is the purification of diesel fuels from sulfur compounds by oxidized methods.

Keywords: hydrocleaning, motor fuel, extraction, oxidation, secondary alcohols, hydrogen peroxide

\section{DOI: 10.15276/opu.3.59.2019.12}

(C) 2019 The Authors. This is an open access article under the CC BY license (http://creativecommons.org/licenses/by/4.0/). 
Introduction. Today, oil is practically the only source of production of motor fuels, which uses more than $50 \%$ of the oil produced. In modern conditions there is a constant decrease in the quality of petroleum raw materials, which is received for processing. On the other hand, environmental requirements for fuel quality are increasing. All this makes it urgent to solve the problem of desalination of commodity petroleum products. In the European Union, the requirements for the amount of sulfur content in motor fuels in accordance with the standard EURO-5 and EURO-6 should not exceed $10 \mathrm{ppm}$ (0.001\% wt.) [1].

Improving the quality of petroleum products is possible due to its processing, namely the removal of sulfur. Practice has shown that engine motors are dependent solely on the temperature of their operation and the sulfur content of the fuel. The use of low sulfur diesel increases the engine overhaul by more than one and a half times [2]. Therefore, desulphurization is one of the major problems in the production of commodity petroleum products.

Analysis of recent publications and problem statement. Catalytic processes in hydrogen, especially hydrotreating, have become most widespread among large-scale secondary refining processes. The purpose of the hydrotreating process is to improve the quality of the distillates by removing the sulfur, nitrogen, oxygen, resinous compounds, and the catalytic hydrogenation of the unsaturated compounds with hydrogen. Hydrotreating is used for the preparation of raw materials for the processes of isomerization, reforming, catalytic cracking [3].

In hydrotreating, almost all aliphatic sulfur compounds are converted to hydrogen sulfide and saturated hydrocarbons are formed, nitrogen and oxygen-containing compounds are converted to ammonia and water, with the simultaneous formation of the corresponding hydrocarbons.

The reactivity of the individual groups of sulfur-containing organic compounds in the crude oil is reduced in the following sequence: mercaptans $>$ disulfides $>$ sulfides $>$ thiopanes $>$ thiophenes $>$ benzthiophenes> dibenzothiophene. Process conditions: temperature $350 \ldots 430{ }^{\circ} \mathrm{C}$, pressure $3 \ldots 10 \mathrm{MPa}$, volumetric flow rate of raw materials $3 \ldots 10 \mathrm{~h}^{-1}$, flow of hydrogen-containing gas $100 . . .900 \mathrm{~m}^{3} / \mathrm{m}^{3}$ raw materials.

Despite the progress made, the focus on oil refining in the oil refining field has been steadily increasing. This is due to such objective factors as the increase in the proportion of sulfur and highsulfur oils, the deepening of oil refining and the increase of requirements for the quality of petroleum products. All works in this method that are aimed at improving the process can be divided into three groups [4]:

1. Improvement of catalysts.

2. Creation of new reactor units.

3. Development of hydro treating plants in combination with other processes.

Methods of modernization of existing hydrotreating plants, which aim to increase the depth of desulfurization, are mainly aimed at increasing the contact time of the gas mixture with the catalyst. This condition can be satisfied by increasing the volume of the catalyst, which allows increasing of the residence time of the gas mixture in the catalyst layer, while maintaining the performance of the installation [5]. This approach requires the replacement of existing reactors with larger reactors or the installation of an additional reactor (in parallel or sequentially to the existing one. Under all equal conditions of the technological regime, the temperature is $10 \ldots 30^{\circ} \mathrm{C}$ higher than in the first one). This allows to increase the degree of hydrotreating of diesel fuel without reducing the productivity by increasing the volume of the catalyst and, therefore, the contact time of the gas mixture with the catalyst. Available systems with one or two coupled reactors create numerous opportunities for layout and upgrade of circuits [6]. However, the processes of hydrotreating have practically reached the limits of their efficiency, because bringing the sulfur content of petroleum products up to $10 \mathrm{ppm}$ and below with the help of hydrotreating requires significant economic costs [7, 8].

One of the alternative ways of desulfurization of petroleum distillates is the oxidation method, which has several significant advantages over the hydrogenation process:

- the relatively low pressure and temperature required for the process;

- high selectivity of sulfur compounds; 
- almost complete separation of sulfide and thiophene sulfur (isolation of these sulfur species by hydrogenation causes difficulties);

- there is no need to use hydrogen.

There is a whole group of methods of oxidative desulfurization. Hydrogen peroxide, organic peracids, peroxomonophosphoric acid, nitrogen oxides, nitric acid, ozone, molecular oxygen can be used as oxidants [9]. Among them, oxidative desulfurization of hydrogen peroxide is the most promising. Oxidation desulfurization is based on the direct treatment of petroleum fractions by an oxidizer to oxidize organic sulfur compounds and further isolate the oxidation products. Sulfur compounds are oxidized to sulfones and sulfoxides, which can then be easily removed by conventional methods of separation (adsorption, extraction), since their properties differ significantly from those of hydrocarbons.

The purpose and objectives of the study. The purpose of the work is the purification of fuel fractions of petroleum products from sulfur-containing organic compounds by oxidation.

The task is to study the process of oxidation of sulfur-organic compounds of petroleum products with hydrogen peroxide and oxygen in the presence of secondary alcohols in order to obtain environmentally friendly fuels.

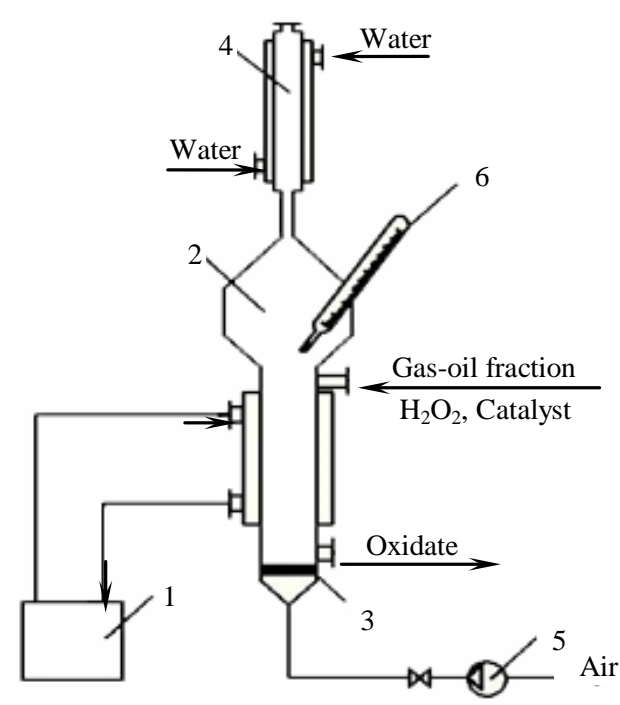

Fig. 1. Installation for the process of oxidation of organic sulfur compounds with hydrogen peroxide: 1 - thermostat; 2 - oxidation reactor; 3 - perforated plate; 4 - water refrigerator; 5 - compressor; 6 - thermometer
Materials and methods of research. The studies were performed on the laboratory unit shown in Fig. 1.

The main part of the laboratory installation is a glass oxidation column 2, equipped with a reflux condenser 4 and a shell, which feeds the coolant from the thermostat 1 . In the lower part of the column soldered porous glass plate 3 , which performs the function of a perforated plate. The foam-emulsion mode is formed by blowing the air with the compressor 5 through the layer of reactants present on the plate. The linear velocity of the air at the full cross section of the reactor is $0.05 \ldots 0.1 \mathrm{~m} / \mathrm{s}$ (controlled by a rotometer).

The straight-run fraction together with the catalyst (a mixture of sulfate and acetic acids) is loaded into the reactor when the air is supplied, heated to a predetermined temperature and the calculated amount of hydrogen peroxide is introduced. The moment of contact of the oxidizer with the raw material is recorded as the beginning of the reaction. After termination of the experiment, the reaction mixture was poured into a flask and quickly cooled to room temperature, transferred to a separating funnel, in which the upper hydrocarbon layer is separated from the aqueous phase, dried with anhydrous calcium chloride. For purification from sulfones and sulfoxides, the hydrocarbon mixture is passed through a glass tube filled with silica gel.

In order to obtain diesel fuels that meet the sulfur content of EURO-5 standard (10 ppm and less), we investigated the method of oxidation of sulfur compounds by hydrogen peroxide in the presence of a catalytic system (a mixture of acetic and sulfuric acids) according to a two-stage scheme [10]. We have found that the presence of unsaturated compounds in it is greatly influenced by the efficiency of the oxidative desulfurization process of diesel. Thus, for hydrotreated diesel and straight-run fuel fractions containing little unsaturated compounds, oxidative desulphurization reduced the sulfur content by $96 \%$. Unsaturated compounds, which are present in large quantities in the products of the secondary processing of oil (cracking, pyrolysis), have a negative effect on oxidative desulfurization. This is due to the expense of the oxidizer on the reactions with unsaturated compounds, the resin formation process, as well as absorption by the absorbers. Table 1 shows the experimental data depending on the degree of purification from the content of unsaturated compounds (bromine number). 
Dependence of the degree of oil purification on the content of unsaturated compounds

\begin{tabular}{c|c|c|c|c}
\hline \multicolumn{5}{c}{ Straight fractions of oil } \\
\hline Fractions & $\begin{array}{c}\text { Sulfur content in } \\
\text { feedstock, ppm }\end{array}$ & Bromine number & $\begin{array}{c}\text { Sulfur content after } \\
\text { purification, ppm }\end{array}$ & $\begin{array}{c}\text { The degree of puri- } \\
\text { fication }\end{array}$ \\
\hline $100 \ldots 180^{\circ} \mathrm{C}$ & 78 & 11.8 & 16.2 & 0.79 \\
\hline $180 \ldots 220^{\circ} \mathrm{C}$ & 185 & 5.8 & 11.2 & 0.94 \\
\hline $220 \ldots 290^{\circ} \mathrm{C}$ & 489 & 3.15 & 17.6 & 0.96 \\
\hline \multicolumn{5}{|c|}{ Car tire pyrolysis oil } \\
\hline $180 \ldots 220^{\circ} \mathrm{C}$ & 8120 & 38 & 7209 & 0.11 \\
\hline $220 \ldots 290^{\circ} \mathrm{C}$ & 7800 & 44 & 7400 & 0.05 \\
\hline
\end{tabular}

The implementation of the oxidative desulfurization method depends on the cost of the oxidant. To clean 1 million tonnes of diesel fuel containing $1 \%$ sulfur, 90.000 tonnes of $30 \%$ hydrogen peroxide is required. The cost of a hydrogen peroxide production plant of this capacity is estimated at around EURO 0.5 billion. Therefore, the method of oxidative desulfurization of hydrogen peroxide can only be used in the combined method with pre-hydrotreating. The direct oxidation of the desulfurization of fuel fractions can be used with a cheaper oxidizer, but oxidation with oxygen alone does not provide sufficient desulfurization [9]. Therefore, we have investigated the process of obtaining hydrogen peroxide, not described in the literature, with oxidation of sulfuric compounds of oil. For this purpose as the oxidant used a mixture of oxygen with secondary alcohols, the interaction of which produces hydrogen peroxide.

Oxidation of sulfuric compounds of oil with oxygen in the presence of secondary alcohols. With oxygen oxidation, the degree of desulfurization was low in the presence of secondary (isobutyl) alcohol of the straight-run fraction of the oil in the foam-emulsion column at $97^{\circ} \mathrm{C}$. The low degree of desulfurization is apparently related to the low oxidation rate of isobutyl alcohol at $97{ }^{\circ} \mathrm{C}$. Good results were obtained when carrying out the process in the presence of isopropyl and isobutyl alcohols at $110 \ldots 115{ }^{\circ} \mathrm{C}$. Isopropyl alcohol boils at $t=82.4{ }^{\circ} \mathrm{C}$, so the oxidation process was carried out at high pressure on the installation shown in Fig. 2.

The main part of the laboratory installation is a tubular reactor, at the bottom of which is a metal nozzle. The oxidative desulfurization process was carried out at a temperature of $110 \ldots 115^{\circ} \mathrm{C}$ with the addition of isopropyl alcohol (10\% vol.). Oxygen delivery rate of $150 \mathrm{~cm}^{3} / \mathrm{min}$ for 10 minutes.

Secondary alcohols are more suitable for the oxidation of sulfur compounds, because they and their oxidation products (acetone, alkyl ketones) are lowboiling and easily distilled off by heavy oil fractions. Diesel fuel with a total sulfur content of 195 ppm was taken for the experiment. The diesel fraction $\left(90 \mathrm{~cm}^{3}\right)$ together with isopropyl or isobutyl alcohol $\left(10 \mathrm{~cm}^{3}\right)$ was loaded into the reactor. The mixture was heated to $110 \ldots 115^{\circ} \mathrm{C}$. When the temperature was reached, maintaining the pressure with the throttle valve, oxygen was supplied. Conducted an experiment with exposure $5 ; 10 ; 20 ; 30 ; 60$ minutes at constant temperature. The dependence of the total amount of sulfur in oxidized diesel fuel on the time of the process is shown in Fig. 3.

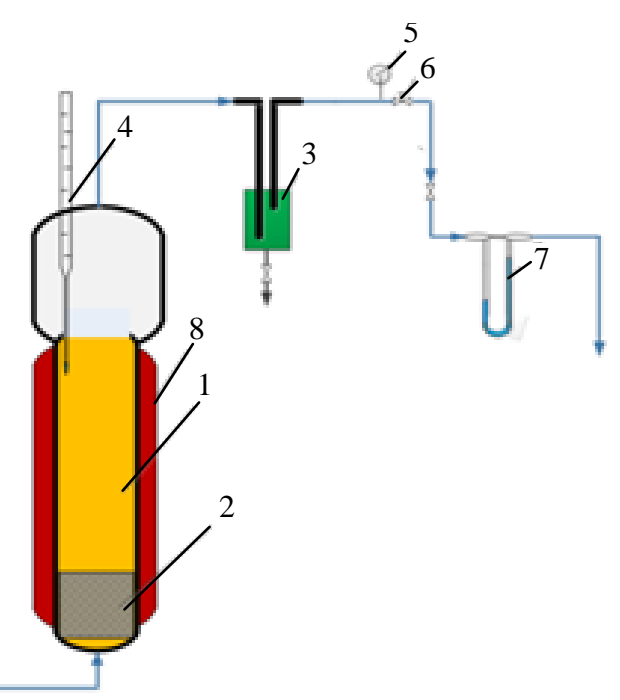

Fig. 2. Installation of oxidation of sulfuric compounds of oil with oxygen in the presence of secondary alcohols: 1 - tubular reactor;

2 - metal nozzle; 3 - separator; 4 -thermometer; 5 - pressure gauge; 6 - throttle valve; 7 - flow meter; 8 - heater 


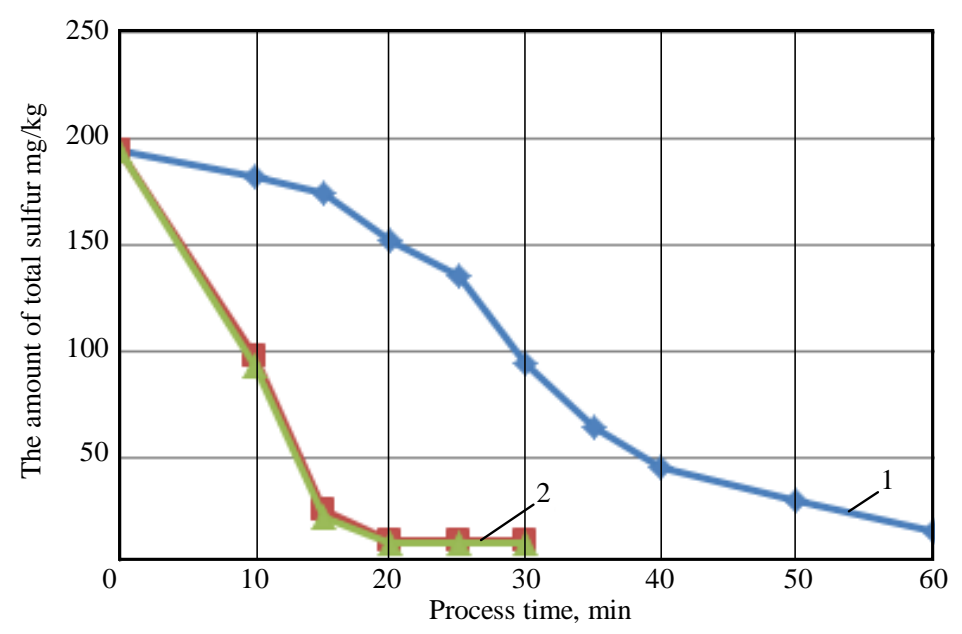

Fig. 3. The dependence of the total amount of sulfur in oxidized diesel fuel from the time of the process: 1 - oxidation of diesel fuel by hydrogen peroxide; 2 - oxidation of diesel fuel by throwing with isopropyl or isobutyl alcohols

The optimal time for the oxidation of diesel fuel with oxygen in the presence of secondary alcohols is 3 times less than when oxidized with hydrogen peroxide. This is due to the higher temperature of the process and the fact that oxygen is better soluble in hydrocarbons than in water. Table 2 gives a comparative characteristic of the oxidation of hydro purified diesel with hydrogen peroxide (A) and oxygen in the presence of secondary alcohol (B).

Table 2

Comparative characteristics of methods of desulphurization of hydrotreated diesel fuel

\begin{tabular}{c|c|c|c|c|c}
\hline Method & $\begin{array}{c}\text { Process } \\
\text { temperature, } \mathrm{C}^{\circ}\end{array}$ & Time, min & $\begin{array}{c}\text { Sulfur content in } \\
\text { feedstock, ppm }\end{array}$ & $\begin{array}{c}\text { Sulfur content after } \\
\text { purification, ppm }\end{array}$ & $\begin{array}{c}\text { The degree of puri } \\
\text { fication }\end{array}$ \\
\hline $\mathrm{A}$ & $96 \ldots 97$ & 60 & 195 & 10 & 0.95 \\
\hline $\mathrm{B}$ & 110 & 20 & 195 & 8.5 & 0.96 \\
\hline
\end{tabular}

Method (B) allows to obtain fuel with a sulfur content below $10 \mathrm{ppm}$ with low capital costs for equipment and low cost of reagents.

Characterization and analysis of raw materials and reagents. As the raw material for the experiment used oil and its fractions, as well as diesel fuel from the gas station "Ukrnafta", with a sulfur content of $195 \mathrm{ppm}$.

The determination of sulfur content was performed by the method of ultraviolet fluorescence on an energy-dispersive X-ray fluorescence analyzer RX-360SH, national standart EN ISO 20884:2012. This standard applies to motor gasoline, including gasoline with a mass fraction of oxygen of not more than $2.7 \%$; diesel, including diesel with a fatty acid methyl ester content not exceeding $5 \%$ (by volume). The standard establishes a method for determining sulfur concentrations in the range of 3 to $500 \mathrm{mg} / \mathrm{kg}$.

To determine the bromine number used the standard method for the determination of bromine numbers of petroleum distillates and aliphatic olefins - national standart 4402:2005.

\section{Conclusions}

It is shown that the efficiency of the oxidative desulfurization process of fuel fractions depends on the content of unsaturated compounds.

The cost-effectiveness of the oxidative desulfurization method can be achieved by a combined oxygen oxidation process in the presence of secondary alcohols.

Combining the process of catalytic hydrotreating with oxidation methods, which complement each other, allows to bring the sulfur content of petroleum products to $10 \mathrm{ppm}$. 


\section{Література}

1. Анищенко О.В., Абел Д.Н., Кузьмин А.С. Вариант решения проблемы гидрообессеривания дизельного топлива. Международный журнал фундоментальных исследований. 2016. № 5. С. 828-829.

2. Шевченко Г.А., Кривцов Н.И. Влияние сернистых соединений на смазывающую способность дизельных топлив. Вестник Томского государственного университета. Химия. 2015. № 2. С. 45-58.

3. Хурамшин Р.Т. Современные катализаторы ОАО «ВНИИ НП» для нефтепереработки. Москва : ВНИИ НП, 2015. $41 \mathrm{c}$.

4. Каталог катализаторов фирмы Sud-Chemie. 2009. URL: https://www.twirpx.com/file/982248/.

5. Лебедев Ю.Н., Чекменев В.Г., Данилов Д.Ю. Испытание новых центробежных тарелок с рециркуляцией жидкости. Химия и технология топлив и масел. 2010. № 4. С. 40-43.

6. Жилина В.А., Самойлов Н.А. Направление модернизации установок гидроочистки дизельного топлива. Нефтегазовое дело. 2017. С. 96-104.

7. Принципы выбора экстракционных систем и комбинированных процессов разделения и очистки нефтепродуктов / Гайле А.А., Залищевский Г.Д., Кайфаджин Е.А., Колдобская Л.Л., Сомов, В.Е. Химия и технология топлив и масел. 2007. № 3. С. 12-14.

8. Wan Mokhtar W., Abu Bakar W., Rusmidah A. Deep desulfurization of model diesel by extraction with N,N- dimethylformamide: Optimization by Box-Behnken design. Taiwan Institute of Chemical Engineers. 2014. № 35. P. 314-319.

9. Анисимов А.В., Тараканова А.В. Окислительное обессеривание углеводородного сырья. Росийский химический журнал. 2008. № 4. С. 32-36.

10. Лялін В.В., Ардинцева А.В., Ключник О.Г., Розробка безперервного способу окисного знесірчення нафтопродуктів. Проблеми хімотологї: матеріали IV міжнар. наук.-техн. конф., м. Одеса, 24-28 верес. 2012 р. Одеса, 2012. С. 46-49.

\section{References}

1. Anishchenko, O.V., Abel, D.N., \& Kuzmin, A.S. (2016). A solution to the problem of hydrodesulfurization of diesel fuel. International Journal of Fundamental Research, 5, 828-829.

2. Shevchenko, G.A., \& Krivtsov, N.I. (2015). The effect of sulfur compounds on the lubricity of diesel fuels. Bulletin of Tomsk State University. Chemistry, 2, 45-58.

3. Khuramshin, R.T. (2015). Modern catalysts of VNII NP OJSC for oil refining. Moscow: VNII NP.

4. Catalog of catalysts from Sud-Chemie. (2009). Retrieved from: https://www.twirpx.com/file/982248/.

5. Lebedev, Yu.N., Chekmenev, V.G., \& Danilov, D.Yu. (2010). Testing of new centrifugal plates with liquid recirculation. Chemistry and technology of fuels and oils, 4, 40-43.

6. Zhilina, V.A., \& Samoilov, N.A. (2017). Direction of modernization of diesel hydrotreatment units. Oil and gas business, 96-104.

7. Gayle, A.A., Zalishchevsky, G.D., Kayfadzhin, E.A., Koldobskaya, L.L., \& Somov, V.E. (2007). Principles of selection of extraction systems and combined processes for the separation and purification of petroleum products. Chemistry and technology of fuels and oils, 3, 12-14.

8. Wan Mokhtar W., Abu Bakar W., \& Rusmidah, A. (2014). Deep desulfurization of model diesel by extraction with N,N- dimethylformamide: Optimization by Box-Behnken design. Journal of the Taiwan Institute of Chemical Engineers, 2014. № 35. P. 314-319.

9. Anisimov, A.V., \& Tarakanova, A.V. (2008). Oxidative Desulphurization of Hydrocarbon Raw Materials. Russian chemical journal, 4, 32-36.

10. Lyalin, V.V, Ardintseva, A.V, \& Klyuchnik, O.G. (2012). Development of a continuous method of oxidative desulfurization of petroleum products. Problems of Chemotology: Materials IV. scientifictechnical conf. 24-28 September. (pp. 46-49.) Odessa.

Лялін Віктор Васильович; Lyalin Victor, ORCID: https://orcid.org/0000-0002-1898-8972

Древницька Олена Леонідівна; Drevnitskaya Yelena, ORCID: https://orcid.org/0000-0003-0473-2156

Received October 05, 2019

Accepted November 25, 2019 